\title{
PENGEMBANGAN SUMBER DANA SEKOLAH PADA SEKOLAH MENENGAH KEJURUAN
}

\author{
M. Agphin Ramadhan \\ Universitas Negeri Jakarta \\ agphin.ramadhan@gmail.com \\ Sugiyono \\ Universitas Negeri Yogyakarta \\ sugiyono_1953@yahoo.com
}

Abstrak

\begin{abstract}
Penelitian ini bertujuan: (1) mengetahui sumber dana sekolah yang selama ini diterapkan; (2) menemukan model pengembangan sumber dana alternatif sekolah, dan (3) mengujicoba keefektifan internal model pengembangan sumber dana sekolah di SMK Bidang Keahlian Teknologi dan Rekayasa. Penelitian ini menggunakan metode research and development. Penelitian dilakukan di SMK negeri dan swasta di kota Yogyakarta. Pengumpulan data penelitian menggunakan wawancara mendalam dan observasi. Hasil penelitian menunjukkan bahwa: (1) sumber dana sebagian besar berasal dari pemerintah dan masyarakat; sumber dana alternatif yang selama ini digali oleh SMK berasal dari penyewaan kantin, unit produksi dan koperasi; dan peran sumber dana alternatif terhadap anggaran belanja operasional sekolah adalah $\leq 0,39 \%$. (2) Hasil pengembangan menghasilkan grand design model pengembangan sumber dana alternatif sekolah yang terdiri dari: model pengelolaan sumber dana dan model pengembangan unit-unit usaha. (3) Hasil uji internal yang dilakukan dapat disimpulkan bahwa ahli setuju: (a) komponen model telah lengkap (84,5\%); (b) struktur komponen model telah jelas (86,3\%); (c) hubungan antar komponen model telah jelas (80,4\%); (d) model memiliki keterbacaan yang baik (82,2\%); (e) model telah layak (88,1\%); dan (f) model efektif jika diimplementasikan (93,3\%).
\end{abstract}

Kata kunci: sumber dana, unit usaha sekolah, dana alternatif, SMK

\section{DEVELOPING THE SOURCE OF SCHOOL FUNDS IN VOCATIONAL SECONDARY SCHOOLS}

\begin{abstract}
This research aims to: (1) reveal the source of school fund model which has been applied; (2) reveal the development model of alternative source of school fund; and (3) test the internal effectiveness of development model of source of school fund in vocational secondary schools (SMK) which run the Study Program of Technology and Engineering Expertise. This research employed the research and development method. This research was conducted at public and private vocational secondary schools in Yogyakarta. The research data were collected using in depth interview and observation. The results of this research show that: (1) the source of the schools' fund is the government and citizens; the alternative source of the schools'fund which has been cultivated by SMK mainly comes from canteen lease, production units, and cooperatives; and the contribution of the alternative source of the schools' fund to the schools' operating budget is $\leq 0.39 \%$. (2) The result of the development showed that the grand design model of alternative source of school fund which consist of source of funds management model and development of business units model. Furthermore, the result of internal effectiveness testing which involved the experts concluded that: (a) the components of the model are sufficient (84,5\%); (b) the structure of the components of the model has been understood (86.3\%); (c) the relationship between the components is clear (80.4\%); (d) the model has good readability (80.4\%); (e) the model is acceptable (88.1\%); and (f) the model is effective if it is implemented (93.3\%).
\end{abstract}

Keywords: $\quad$ source of fund, school business unit, alternative fund, SMK 


\section{PENDAHULUAN}

Sumber Daya Manusia (SDM) adalah salah satu indikator yang menjadi alat ukur kemajuan suatu bangsa. Permasalahan krusial yang dihadapi bangsa Indonesia berkaitan tentang pemberdayaan SDM. Berbagai permasalahan SDM Indonesia antara lain: persebaran penduduk antar daerah yang tidak merata; pertumbuhan angkatan kerja lebih tinggi dibanding ketersediaan lapangan kerja; ketidaksesuaian kompetensi SDM dengan kompetensi yang dibutuhkan di dunia kerja; dan tingginya tingkat pengangguran sebanding dengan kemiskinan menyebabkan rendahnya kualitas pendidikan, pada akhirnya menyebabkan rendahnya kualitas SDM Indonesia. Jumlah SDM Indonesia yang merupakan empat terbesar di dunia seperti sebuah mata pisau, sangat menguntungkan jika dimanfaatkan dengan baik, dan sangat merugikan jika tidak dimanfaatkan secara maksimal.

Publikasi The Global Competitiveness Report yang diterbitkan oleh Forum Ekonomi Dunia dapat diketahui bahwa tingkat kompetitif negara-negara di dunia. Berdasarkan Growth Competitiveness Index tahun 2013 - 2014 Indonesia menempati urutan 38 dari 148 negara. Hal ini merupakan prestasi karena tahun sebelumnya Indonesia hanya menempati urutan 50 dari 144 negara. Namun demikian, bila dibandingkan dengan negara-negara ASEAN, Indonesia relatif masih tertinggal. Singapura merupakan negara yang peringkat daya saingnya tertinggi diikuti oleh Malaysia (24), Brunei Darussalam (26), dan Thailand (37). Indonesia berada di urutan kelima (38), sementara Filipina, Vietnam, Laos, Kamboja, Timor-Leste, dan Myanmar berada di urutan 6 - 11. Sedangkan berdasarkan indikator Pendidikan Tinggi dan Pelatihan, dari sebelas negara ASEAN Indonesia berada di urutan 4 (urutan 64 dari 148 negara) tertinggal jauh oleh negara tetangga Singapura (urutan 2 dari 148 negara) dan Malaysia (urutan 46 dari 148 negara).

Upaya peningkatan kualitas SDM dilaksanakan melalui berbagai sektor pembangunan, antara lain: kesehatan, kesejahteraan sosial, kependudukan, dan tenaga kerja. Salah satu sektor penting lainnya adalah pendidikan. Technological change promotes demand for education, and education promotes technological change. Technological change leads to economic competitiveness and economic growth. Therefore, education is associated with these factors (Marginson, 1993 dalam Pavlova, 2009, p. 12). Pendidikan berkaitan erat dengan perubahan teknologi dan pertumbuhan ekonomi suatu negara. Pendidikan merupakan bentuk investasi jangka panjang yang memberikan sumbangan besar terhadap pembangunan ekonomi. Investasi pendidikan memberikan nilai balik (rate of return) yang lebih tinggi dari pada investasi fisik di bidang lain. Sebuah temuan dapat ditunjukkan bahwa keuntungan ekonomi dari investasi pendidikan, tingkat baliknya ternyata lebih tinggi daripada investasi fisik dengan perbandingan rata-rata $15,3 \%$ dan $9,1 \%$. Ini menunjukkan bahwa investasi di bidang pendidikan sangat menguntungkan, baik secara sosial maupun ekonomi (Bappeda Jabar, 2002 dalam Fattah, 2012, p. 41).

Salah satu jenis pendidikan yang disebutkan dalam Undang-Undang Nomor 20 Tahun 2003 tentang Sistem Pendidikan Nasional adalah pendidikan kejuruan. Dalam pasal 15 dinyatakan bahwa pendidikan kejuruan adalah pendidikan menengah yang mempersiapkan peserta didik terutama untuk bekerja dalam bidang tertentu. Pendidikan kejuruan atau vocational education dikatakan efisien jika mampu menjamin pasokan tenaga kerja (output) secara memadai terhadap kebutuhan tenaga kerja. Satu prinsip dasar pendidikan kejuruan adalah masyarakat dilatih pada pekerjaan tertentu yang diperlukan oleh masyarakat/ pasar kerja (demand) (Thompson, 1973). Dikmenjur (2006) menyatakan bahwa tujuan SMK adalah menyiapkan lulusannya untuk dapat bekerja baik secara mandiri maupun mengisi lowongan pekerjaan sesuai dengan keahliannya. Setelah beberapa dasawarsa, SMK di Indonesia telah mampu memasok tenaga kerja. Namun yang kini menjadi masalah adalah jumlah tenaga kerja yang lebih banyak dibandingkan kebutuhan. Sehingga menyebabkan tingkat pengangguran lulusan SMK terbilang tinggi. 
Badan Pusat Statistik (BPS) mencatat jumlah pengangguran pada Agustus 2013 mencapai 7,4 juta orang dengan tingkat pengangguran terbuka (TPT) sebesar $6,25 \%$. TPT Agustus 2013 mengalami kenaikan dibanding Februari 2013 5,92\% dan Agustus 2012 6,14\%. Jika ditilik dari pendidikannya, TPT untuk pendidikan SMK menempati posisi tertinggi yakni sebesar $11,19 \%$. Jumlah ini meningkat dibandingkan yang tercatat Agustus 2012 9,87\% (Republika, 6 November 2013). Banyak faktor yang menyebabkan lulusan SMK belum mendapat pekerjaan, minimnya kompetensi yang dikuasai, program keahlian yang tidak sesuai dengan perkembangan zaman, belum adanya kerjasama yang baik antara sekolah dan DU/DI akibatnya pembelajaran di SMK tidak sesuai dengan yang dibutuhkan di DU/DI. Hal ini yang menjadi tantangan pendidikan kejuruan khususnya di Indonesia dan umumnya di regional ASEAN. Seperti yang dijelaskan oleh Specht, Feder, dan Aipperspach (2014, p. 7)

The biggest challenge for TVET in the ASEAN region in 2015 lies in an active and sustained participation in TVET, not only of large companies and corporations, but also of the SME sector and the informal sector to achieve a demand-oriented qualification of well-skilled laborers and specialists at all levels.

Ketidaksesuaian kompetensi yang dibutuhkan dan kurangnya dukungan dari DU/DI inilah yang menyebabkan kualitas pembelajaran SMK dipertanyakan..

Kualitas lulusan selalu berhubungan dengan proses pembelajaran dan fasilitas pendukung, proses pembelajaran dan fasilitas jika ditarik benang merah berkaitan dengan dana. Hasil penelitian yang dilakukan oleh Greenwald, Hedges, \& Laine (1996, p. 361) menyatakan bahwa secara umum uang memang sangat berpengaruh dalam peningkatan kualitas pendidikan. Thomas (1985) dalam Fattah (2012, p. 42) menyatakan bahwa Finance is necessary but not sufficient condition for educational excellence. It is recognized too that finance is one of several perspective that are essential in understanding and analysing education.
Masalah yang dihadapi oleh pendidikan kejuruan berkaitan dengan keterbatasan dana. Hal ini diperkuat oleh Gasskov (2000, p. 201) menegaskan bahwa masalah utama yang muncul di beberapa negara adalah kurangnya pendanaan pendidikan kejuruan dikarenakan keterbatasan anggaran pendidikan negara. Tantangan lain khususnya pada negara yang memiliki keterbatasan sumber daya pendidikan adalah kebutuhan untuk menggunakan dana dengan cara yang efisien. Selain itu, biaya pendidikan kejuruan lebih tinggi dibanding pendidikan umum lainnya. Menurut Gill (2008, p. 184) bahwa rerata unit cost Sekolah Menengah Kejuruan (SMK) 40\% lebih tinggi dibandingkan dengan sekolah menengah umum. Sementara itu, berdasarkan data rerata biaya operasional non-personalia antara sekolah kejuruan (kelompok program studi keahlian Teknik Bangunan) lebih besar 49.10\% dibandingkan dengan sekolah menengah umum (Permendiknas No. 69; 2009).

Hasil kajian dan analisis investasi pendidikan di Indonesia di tingkat pemerintah Kabupaten/ Kota yang dilakukan oleh Bank Dunia (The World Bank, 2008) bahwa dana pendidikan untuk sekolah dasar dan menengah dihitung berdasarkan unit cost per masingmasing siswa dikalikan dengan jumlah murid yang aktif di sekolah tersebut. Metode pengalokasian dana pendidikan yang dilakukan oleh Pemerintah, Pemerintah Daerah Provinsi, dan Pemerintah Daerah Kabupaten/Kota secara eksplisit tampak bahwa besaran unit cost tidak dihitung berdasarkan aktivitas pembelajaran yang sesuai dengan jenis pendidikan. Hal tersebut menjadi permasalahan tersendiri karena kebutuhan dana penyelenggara pendidikan di SMA berbeda dengan di SMK, yang tentunya besaran unit cost di SMK lebih besar. Klein (2011, p. 4) memperkuat pernyataan tersebut dengan menyatakan bahwa penyelenggaraan pendidikan kejuruan secara umum diasumsikan memerlukan biaya yang lebih besar dibanding pendidikan lainnya.

Beberapa pernyataan di atas tampak bahwa pembiayaan penyelenggaraan pendidikan kejuruan memerlukan dana yang besar, tentunya didasarkan baik pada kajian secara teoretik maupun empiris sesuai dengan fakta 
di lapangan. Tingginya dana pendidikan kejuruan dibanding pendidikan umum lainnya dikarenakan pembentukan skills competencies melalui pembelajaran praktik lebih besar dibandingkan cognitive competencies yang diberikan melalui teori. Hal tersebut disebabkan beberapa biaya yang dibutuhkan, antara lain: pembelian peralatan praktik, bahan praktik, perawatan peralatan, gaji instruktur, dan pembelian sumber energi.

Pembiayaan pendidikan kejuruan yang tinggi ternyata berbanding terbalik dengan tingkat ekonomi orang tua peserta didik di SMK. Sebagian besar orang tua peserta didik di SMK memiliki kondisi sosial-ekonomi menengah ke bawah. Penelitian yang dilakukan oleh Windarto (2013, p. 103) menyatakan bahwa terdapat pengaruh yang signifikan antara kesejahteraan keluarga dengan minat siswa SMP di Kabupaten Bantul dalam melanjutkan sekolah ke SMK. Orangtua yang memiliki latar belakang sebagai orang tidak mampu dapat memberikan minat yang positif bagi anaknya untuk melanjutkan sekolah ke SMK. Orang tua yang memiliki latar belakang ekonomi menengah ke bawah, akan mendukung atau menyekolahkan anaknya ke SMK dengan harapan setelah lulus sekolah dapat langsung melanjutkan ke dunia kerja. Kondisi ini ternyata tidak hanya terjadi di Indonesia, Harris, Simon, dan Moore (2005, p. 10) melaporkan temuan penelitian bahwa pelaksanaan kerjasama pembelajaran model magang yang diselenggarakan Technical and Further Education (TAFE) di Australia lebih banyak diikuti oleh kelompok masyarakat ekonomi rendah. Jadi pendidikan kejuruan di Australia juga masih dipandang sebagai pendidikan yang kurang bergengsi oleh masyarakatnya. Greenwood (2005, p. 407) menyatakan "... We are still stuck and in a groove of thinking that the practical vocational courses are inferior to more academic studies".

Komitmen pemerintah dalam meningkatkan kualitas pendidikan diwujudkan dalam pemberian bantuan operasional sekolah. Pemerintah sejak tahun 2005 telah menerapkan Bantuan Operasional Sekolah (BOS). BOS awalnya diberikan pada tingkat dasar dan menengah pertama, kemudian sejak tahun 2013
BOS diberikan pula pada tingkat menengah atas, termasuk SMK. BOS SMK diberikan dalam bentuk dana langsung ke SMK Negeri maupun Swasta untuk membantu biaya operasional sekolah nonpersonalia. Besar dana bantuan yang diterima sekolah dihitung berdasarkan jumlah siswa masing-masing sekolah dikalikan satuan biaya (unit cost) bantuan (Dit.PSMK, 2014). Selain itu bantuan BOS yang diberikan oleh pemerintah pusat, Pemerintah Daerah Provinsi juga memberikan bantuan yang disebut Bantuan Operasional Sekolah Daerah (BOSDA).

Prinsip BOS maupun BOSDA SMK diperuntukkan untuk siswa yang sekolahnya merupakan SMK negeri atau swasta dan memiliki izin operasional. Peruntukan dana BOS SMK diatur pada Petunjuk Teknis BOS SMK (2014) dan mengacu pada Permendiknas No. 69 Tahun 2009 meliputi: (1) pembelian/ penggandaan buku teks pelajaran, (2) pembelian alat tulis sekolah yang digunakan untuk kegiatan pembelajaran, (3) penggandaan soal dan penyediaan lembar jawaban siswa dalam kegiatan ulangan dan ujian, (4) pembelian peralatan pendidikan, (5) pembelian bahan praktik habis pakai, (6) pemeliharaan dan perbaikan ringan sarana prasarana sekolah, (7) operasional layanan sekolah berbasis TIK, (8) penyelenggaraan kegiatan uji kompetensi siswa, (9) penyelenggaraan praktek kerja industri (dalam negeri), (10) langganan dan jasa lainnya, (11) kegiatan penerimaan siswa baru, (12) penyusunan dan pelaporan, dan (13) mendukung implementasi kurikulum 2013.

Di samping butir-butir tersebut di atas, bagi SMK yang ditetapkan sebagai SMK Rujukan dapat menggunakan dana BOS untuk koordinasi yang berkaitan dengan Rencana/ Pelaksanaan tentang Pengembangan SMK Rujukan. SMK Rujukan adalah SMK yang memiliki kinerja unggul, akses besar, dan efektif dalam mengelola institusi. Menurut Direktur PSMK, Mustaghfirin Amin (2014), ada beberapa kriteria yang harus dipenuhi sekolah untuk bisa ditetapkan menjadi SMK Rujukan, yaitu: (a) Memiliki siswa lebih dari 1000 orang, dan berkarakter baik; (b) Guru yang produktif; (c) Jaringan kerjasama industri; (d) Memiliki fasilitas dasar yang baik; 
(e) Telah menghasilkan lulusan dengan nilai ujian nasional yang baik; (f) Lokasi sekolah yang strategis (Setkab, 16 April 2014).

Bantuan Operasional Sekolah Daerah (BOSDA) yang diberikan oleh Pemerintah Daerah D.I Yogyakarta bertujuan untuk mendukung program Pendidikan Menengah Universal dan Rintisan Wajib Belajar 15 tahun yang telah dicanangkan pemerintah pada tahun 2012 melalui Peraturan Menteri Pendidikan dan Kebudayaan nomor 80 Tahun 2013. Selain itu, BOSDA Pemerintah Daerah D.I Yogyakarta digunakan untuk memenuhi kekurangan dan/ atau melengkapi Bantuan Operasional Sekolah (BOS) dari pemerintah pusat. Berdasarkan Juknis BOSDA Pendidikan Menengah D.I Yogyakarta (2014) besaran dana yang diberikan untuk SMK adalah Rp 510.000 per siswa. Komitmen Pemerintah Daerah dalam mendukung Pendidikan Menengah Universal dan wajib belajar 12 tahun juga diwujudkan dalam bentuk Jaminan Pendidikan Daerah (JPD) yang diberikan oleh Pemerintah Daerah Kota Yogyakarta bagi masyarakat pemegang Kartu Menuju Sejahtera (KMS). Berdasarkan Lampiran Keputusan Walikota Yogyakarta Nomor 580/Kep/2011 besaran dana yang diberikan Rp 3.000.000,- untuk siswa SMK negeri dan swasta kelas X, dan Rp 2.550.000 untuk siswa SMK negeri dan swasta kelas XI dan XII002E

Pra survey yang dilakukan di beberapa SMK Bidang Keahlian Teknologi dan Rekayasa di wilayah Kota Yogyakarta yang dilaksanakan pada bulan Agustus 2014 diperoleh data bahwa: pertama, alokasi dana bantuan penyelenggaraan pendidikan di SMK pemerintah, Pemerintah Daerah Provinsi, dan Pemerintah Daerah Kabupaten/ Kota tidak berdasarkan kebutuhan riil penyelenggaraan pendidikan. Kedua, sumber dana yang pasti (fix resources) dan bersifat rutin tahunan tidak mencukupi untuk proses pembelajaran, perawatan prasarana gedung, perawatan prasarana pembelajaran, dan peralatan laboratorium/workshop, serta kebutuhan upgrading peralatan untuk mengikuti perkembangan teknologi di dunia usaha dan industri. Ketiga, SMK belum mampu memaksimalkan potensinya dalam mengembangkan sumber dana alternatif sekolah. Terakhir, pengelola sekolah mengalami kesulitan dalam melakukan pengembangan sumber-sumber dana alternatif sekolah yang melibatkan partisipasi masyarakat dan DU/DI.

Adanya permasalahan di atas, maka SMK bidang keahlian Teknologi dan Rekayasa memerlukan model pengembangan sumber-sumber dana alternatif sekolah. Model pengembangan ini diharapkan dapat mewujudkan SMK yang memaksimalkan potensi unit-unit usaha sekolah yang mandiri dan dapat dimanfaatkan siswa SMK sebagai pembelajaran yang berbasis kewirausahaan.

\section{METODE PENELITIAN}

Hasil akhir penelitian ini adalah ditemukannya model pengembangan sumber dana sekolah di SMK. Oleh karena itu penelitian ini menggunakan metode Penelitian dan Pengembangan (Research and Development) yang dikembangkan oleh Borg \& Gall (1989) namun terbatas pada tiga tahap, yaitu: studi pendahuluan, pengembangan model, dan pengujian internal model

\section{Jenis Penelitian}

Sebelum dikembangkan model sumber dana sekolah di SMK, dilakukan need assessment yang bertujuan sebagai penelitian untuk mengetahui kebutuhan atau gambaran awal mengenai sumber dana di SMK. Penelitian yang dilakukan menggunakan pendekatan kualitatif.

\section{Waktu dan Tempat Penelitian}

Penelitian ini dilaksanakan pada bulan November 2014 sampai dengan Februari 2015. November - Desember 2014 digunakan untuk menganalisis kebutuhan, Desember 2014 Januari 2015 mengembangkan pola sumbersumber dana sekolah, sedangkan Januari - Februari 2015 digunakan untuk uji coba/ validasi model dan uji keefektifan internal.

Lokasi penelitian yang dipilih adalah enam SMK Bidang Keahlian Kelompok Teknologi dan Rekayasa di Kota Yogyakarta yang terdiri dari: SMK Negeri 2 Yogyakarta, SMK Muhammadiyah 3 Yogyakarta, SMK Negeri 3 Yogyakarta, SMK Perindustrian 
Yogyakarta, SMK PIRI 1 Yogykarta, dan SMK Taman Siswa Jetis. Keenam SMK tersebut adalah SMK Kluster dan SMK Non-Kluster yang berada di Kota Yogyakarta.

\section{Responden Penelitian}

Responden penelitian terdiri dari kepala sekolah, wakil kepala sekolah bidang humas, wakil kepala sekolah bidang sarana prasarana, bendahara sekolah, koordinator UPS, koordinator koperasi, dan kantin sekolah. Jenis data yang dijaring berkaitan dengan pengelolaan sumber dana sekolah dan operasional unit usaha sekolah dalam hal fungsi manajemen.

\section{Prosedur}

Penelitian dan pengembangan ini dilakukan melalui tiga tahap. Tahap pertama merupakan penelitian yang dimaksudkan untuk memperoleh informasi awal mengenai model sumber dana sekolah. Tahap kedua merupakan tahap perencanaan atau desain awal pengembangan model sumber dana sekolah. Tahap ketiga merupakan tahap pengembangan model. Pada tahap ini dilakukan validasi model dan uji keefektifan internal. Validasi model dilakukan oleh ahli manajemen pendidikan, ahli pendidikan kejuruan, dan birokrat dinas pendidikan kota Yogyakarta. Sedangkan uji keefektifan internal dilakukan terhadap masing-masing pengelola sekolah.

\section{Teknik Pengumpulan Data}

Teknik pengumpulan data yang digunakan dalam penelitian ini adalah: (1) observasi langsung di lokasi penelitian dengan dibantu alat perekam gambar dan suara, (2) wawancara mendalam kepada semua responden yang telah ditentukan, dan (3) melihat dokumen yang ada di sekolah yang meliputi: RAPBS, unit usaha sekolah yang telah beroperasi, laporan keuangan sekolah, dan data-data lain yang dibutuhkan.

\section{Teknik Analisis Data}

Data yang didapat yang merupakan hasil wawancara, pengamatan, dan dokumentasi dianalisis dan diinterpretasi untuk memenuhi tuntutan tujuan penelitian dan informasi lainnya. Agar penyajian data lebih bermakna dan mudah dipahami maka langkah analisis data yang digunakan dalam penelitian ini menggunakan analysis interactive model dari Miles dan Huberman (1994, p. 23) yang membagi kegiatan analisis menjadi beberapa bagian, yaitu: pengumpulan data, reduksi data, penyajian data, dan penarikan kesimpulan.

\section{Hasil Penelitian dan Pembahasan}

Berdasarkan wawancara, observasi, dan dokumentasi yang dilakukan di enam SMK dapat digambarkan model sumber dana SMK negeri dan swasta.

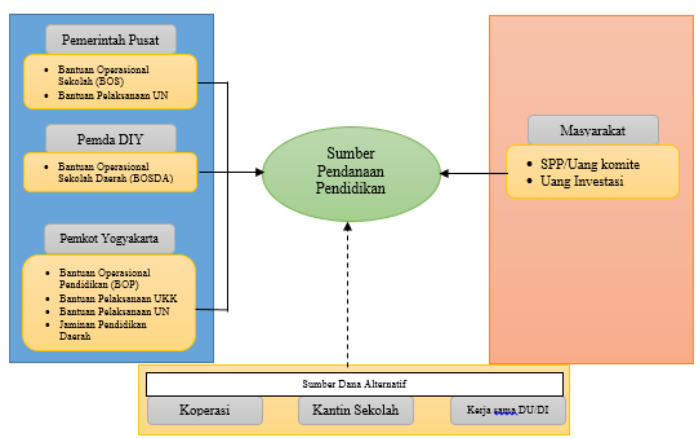

Gambar 1. Model Sumber Dana pada SMK Negeri di Kota Yogyakarta

Pada Gambar 1 dapat dijelaskan bahwa sumber dana pada SMK negeri di Kota Yogyakarta berasal dari bantuan pemerintah, baik pusat, provinsi, dan kota. Selain itu, masyarakat juga berperan dalam sumber pendanaan pendidikan melalui uang komite dan uang investasi. Sumber dana alternatif berasal dari koperasi, kantin, dan kerja sama DU/DI. Dari ketiga sumber dana alternatif tersebut yang memberikan sumbangsih terbesar adalah kantin sekolah.

Unit Produksi Sekolah (UPS) di SMK negeri Kota Yogyakarta tidak berjalan. Hal ini disebabkan karena terkendala regulasi. Berdasarkan UU No. 17 tahun 2003 tentang Keuangan Negara, dimana saat ini diterapkan sistem pengelolaan on-budget, yang intinya mewajibkan setiap penerimaan dan pengeluaran keuangan negara dimasukkan dalam sistem pengelolaan anggaran, dalam hal ini melalui APBN/APBD; sehingga setiap pemanfaatan aset negara yang menghasilkan penerimaan negara harus disetorkan ke negara sebelum bisa digunakan oleh unit kerja pemerintah di 
pusat atau daerah. Dalam hal pemanfaatan pendapatan yang diperoleh dari aktifitas UPS, yang menggunakan aset daerah, secara langsung oleh pihak sekolah, hal tersebut bertentangan dengan UU No. 17 Tahun 2003.

Model sumber dana sekolah pada SMK swasta dapat digambarkan pada gambar 2 .

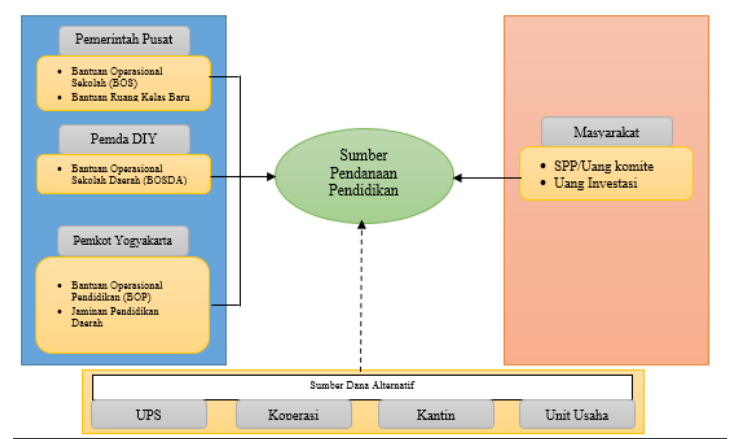

Gambar 2. Model Sumber Dana pada SMK Swasta di Kota Yogyakarta

Pada Gambar 2 dapat dijelaskan bahwa sumber dana pada SMK swasta di Kota Yogyakarta berasal dari masyarakat berupa sumbangan proses pembelajaran (SPP) dan uang investasi. SMK swasta juga mendapat bantuan dari pemerintah pusat, provinsi, dan kota namun nominalnya lebih rendah dibanding SMK negeri. Sumber dana alternatif berasal dari UPS, koperasi, kantin, dan unit usaha lain. UPS di SMK swasta masih berjalan namun tidak memberikan keuntungan yang signifikan, begitu pula dengan koperasi sekolah. Sumber dana alternatif yang memberikan sumbangsih terbesar berasal dari penyewaan kantin. Unit usaha yang dilaksanakan di SMK swasta antara lain: jasa perkreditan laptop dan motor, pertokoan, foto kopi, dan iuran guru karyawan.

Berdasarkan uraian tersebut, ditemukan beberapa kelemahan dalam pengelolaan pendanaan dan pengembangan unit usaha sekolah, yaitu: (1) Pengelolaan dan pengembangan unit usaha sekolah yang belum optimal. Pengelola SMK, khususnya SMK swasta menjadikan uang komite sekolah dan bantuan pemerintah sebagai sumber dana utama; (2) Belum tersosialisasikan dengan baik regulai terkait pelaksanaan Unit Produksi (UP) khususnya di SMK negeri yang notabene aset-aset tersebut adalah milik negara sehingga keuntungan yang didapat harus masuk kas negara; (3) Dalam pelaksanaannya, siswa SMK swasta banyak yang menunggak uang komite sehingga pengelola SMK merasa terbebani dengan kondisi seperti ini; (4) Organisasi unit usaha sekolah, seperti unit produksi, koperasi sekolah, dan lain sebagainya diemban oleh guru yang belum sesuai dengan kompetensi dan profesionalitas; (5) Pelaksanaan yang kurang professional sehingga pendapatan yang dihasilkan sangat minim (6) Kurangnya fungsi pengawasan dan evaluasi sehingga unit usaha sekolah seperti hidup segan mati tak mau; (7) Kepemimpinan kepala sekolah sangat mempengaruhi usaha sekolah dalam mencari sumber dana alternatif. Berdasarkan hasil wawancara dan observasi di SMK swasta kepala sekolah belum memiliki jiwa kewirausahaan; (8) Usaha yang dilakukan sekolah belum terintegrasi sehingga satu sama lain bersaing untuk menghidupkan usahanya masing-masing.

Berdasarkan beberapa kelemahan di atas, selanjutnya dikembangkan model sumber dana sekolah pada SMK yang terdiri dari model pengelolaan sumber dana dan model pengembangan Unit Usaha Sekolah. Model tersebut dilakukan uji coba tahap 1 dan tahap 2. Selanjutnya dihasilkan berupa model operasional:

\section{Pola Sumber Dana Sekolah pada SMK}

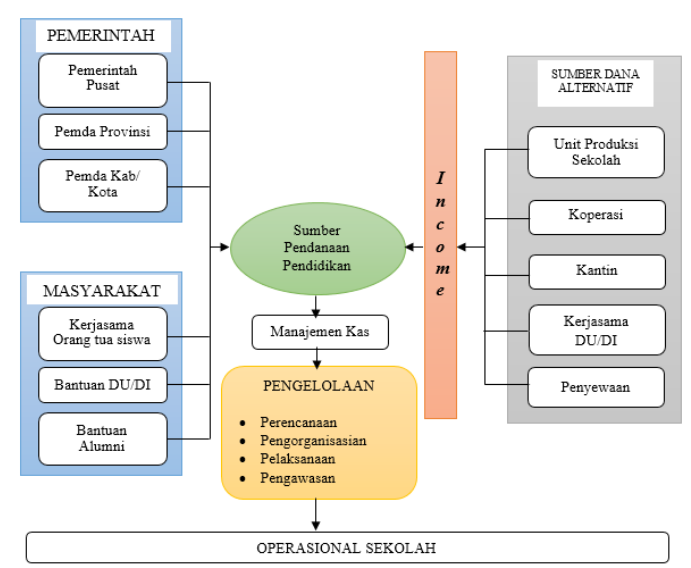

Gambar 3. Model Akhir Pola Sumber Dana Sekolah pada SMK

Pola pada Gambar 3 dapat dijelaskan bahwa untuk meningkatkan pendanaan SMK dapat dikembangkan melalui model pengelolaan 
sumber dana dan model pengembangan Unit Usaha Sekolah. Model pengelolaan sumber dana dilakukan dalam empat tahap, yaitu: perencanaan, pengorganisasian, pelaksanaan, dan pengawasan. Sedangkan model pengembangan Unit Usaha Sekolah (sumber dana alternatif) terdiri dari: UPS, Koperasi Sekolah, Kantin, Kerja sama DU/DI, dan Penyewaan. Operasional dari kelima unit usaha tersebut diharapkan dapat mendatangkan penghasilan/income.

\section{Alur Pengelolaan Sumber Dana Sekolah pada SMK}

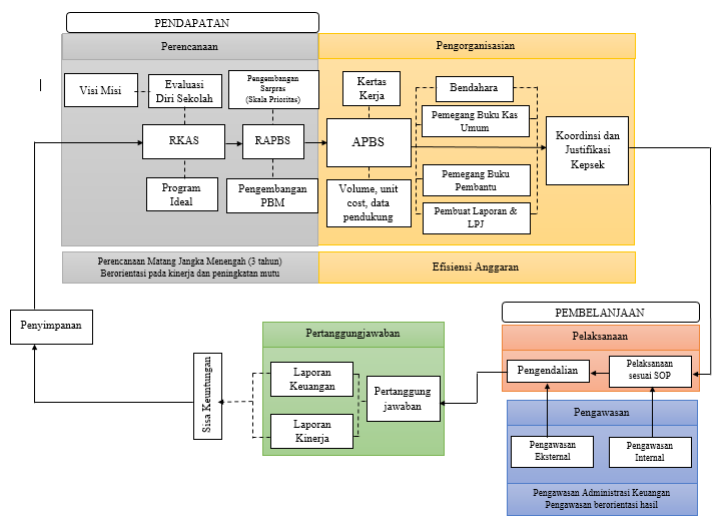

Gambar 4. Model Akhir Alur Pengelolaan Sumber Dana Sekolah pada SMK

Menurut Nurhadi (2011, p. 249) dua diantara empat kelemahan struktural dalam sistem pendanaan pendidikan dewasa ini adalah inefisiensi dalam alokasi anggaran dan penyelenggaran lembaga pendidikan. Oleh karena itu untuk memotivasi satuan pendidikan meningkatkan efisiensi, dapat mempraktikkan tabungan dalam sistem anggaran pemerintah. Tabungan dapat digunakan untuk membantu aliran dana.

Diagram tersebut dapat dijelaskan bahwa dalam pengelolaan sumber dana SMK dilakukan beberapa tahapan, yaitu: (1) perencanaan; (2) pengorganisasian; (3) pelaksanaan; (4) pengawasan; dan (5) pertanggungjawaban. Hal yang ditekankan pada model ini adalah (1) perencanaanmatang anggaranjangkamenengah selama 3 tahun dan berdasarkan pada evaluasi diri sekolah; (2) pengelolaan pendanaan yang berorietasi hasil dan peningkatan mutu; (3) pelaksanaan/pembiayaan yang berasaskan efisiensi; (4) pengawasan dalam bentuk administrasi keuangan dan hasil kinerja; dan (5) sistem akuntansi yang fleksibel, artinya sisa keuntungan dapat disimpan dan digunakan pada perencanaan periode berikutnya.

\section{Pola Pengembangan Unit Usaha Sekolah pada SMK}

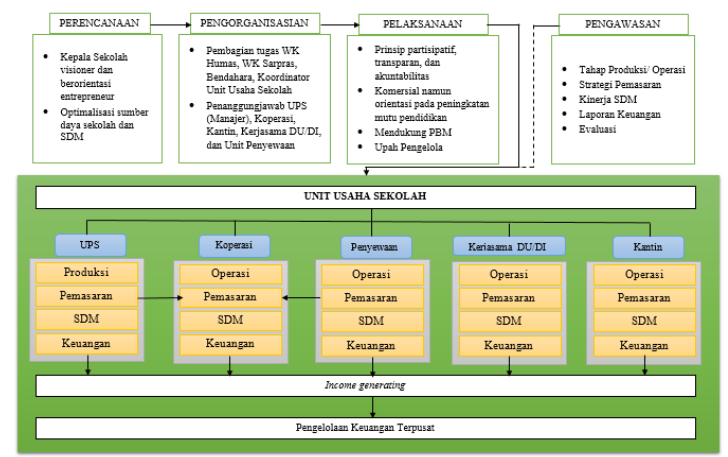

Gambar 5. Model Akhir Pola Pengembangan Unit Usaha Sekolah pada SMK

Unit Usaha Sekolah didirikan untuk menghasilkan income sebagai sumber dana alternatif bagi SMK. Agar penggalian sumber dana alternatif tersebut tepat sasaran, pengelola SMK perlu melakukan environment scanning sehingga usaha yang dilakukan dapat memberikan keuntungan yang sesuai harapan. Diagram di atas dapat dijelaskan bahwa pengembangan unitusaha SMK dapat dilakukan melaui tahap: (1) Perencanaan. Kepala sekolah dituntut untuk menjadi seorang pemimpin yang visioner dan berorientasi entrepreneur, serta didukung oleh sumber daya sekolah dan SDM. (2) Pengorganisasian. Pembagian tugas dengan SDM yang terlibat, mewujudkan aspek partisipatif. (3) Pelaksanaan. Unit Usaha Sekolah dilaksanakan secara komersial namun berorientasi pada peningkatan mutu pendidikan. (4) Pengawasan. Operasional pada unit usaha dapat dilakukan pengawasan, baik terhadap hasil produk, strategi pemasaran, kinerja SDM, dan laporan keuangan.

Unit Usaha Sekolah yang dijalankan terdiri dari: (1) Unit Produksi Sekolah; (2) Koperasi Sekolah; (3) Kantin; (4) Kerja sama DU/DI; dan (5) Unit Penyewaan. Unit usaha sekolah menjalankan produksi dan operasi masing-masing. Bagian pemasaran UPS dan Unit Penyewaan berkoordinasi dengan bagian pemasaran Koperasi Sekolah. Pengelolaan 
keuangan dilakukan secara terpusat sehingga jumlah pendanaan dapat terpantau dengan baik.

\section{Pola Pengelolaan Unit Produksi Sekolah pada SMK}

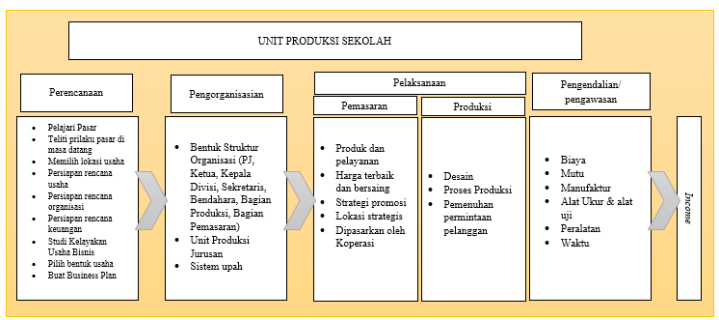

Gambar 6. Model Akhir Pola Pengelolaan

Unit Produksi Sekolah pada SMK

Diagram di atas dapat dijelaskan bahwa pengelolaan Unit Produksi Sekolah dapat dilakukan dengan: (1) perencanaan bisnis yang matang; (2) SDM yang terlibat profesional dan sistem upah yang proporsional; (3) pengembangan Unit Produksi Jurusan; (3) strategi pemasaran yang baik dan berkolaborasi dengan tim pemasaran koperasi; dan (4) pengendalian mutu, biaya, dan waktu.

\section{Pola Pengelolaan Koperasi Sekolah pada SMK}

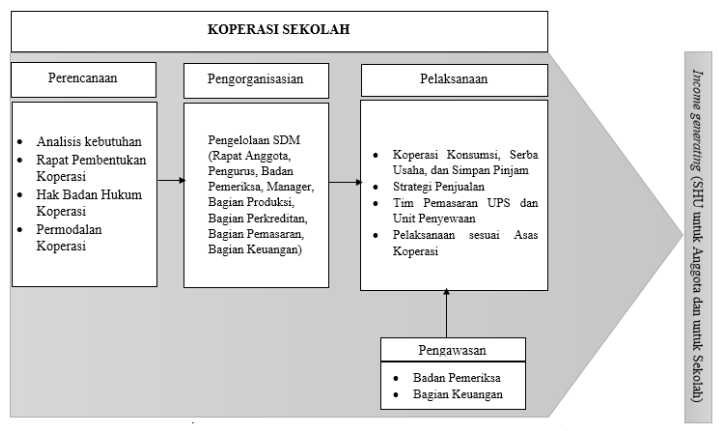

Gambar 7. Model Akhir Pola Pengelolaan Koperasi Sekolah pada SMK

Pola berikut dapat dijelaskan bahwa pengelolaan Koperasi Sekolah dapat dilakukan dengan: (1) pendirian koperasi yang berbadan hukum dan menganalisis kebutuhan; (2) pemodalan yang jelas dan sesuai asas koperasi; (3) SDM yang mendukung dan pembagian tugas yang jelas; (4) pengawasan yang dilakukan oleh Badan Pemeriksa; dan (5) bagian pemasaran yang turut aktif memasarkan produk UPS dan jasa Unit Penyewaan.

\section{Pola Pengelolaan Kantin Sekolah pada SMK}

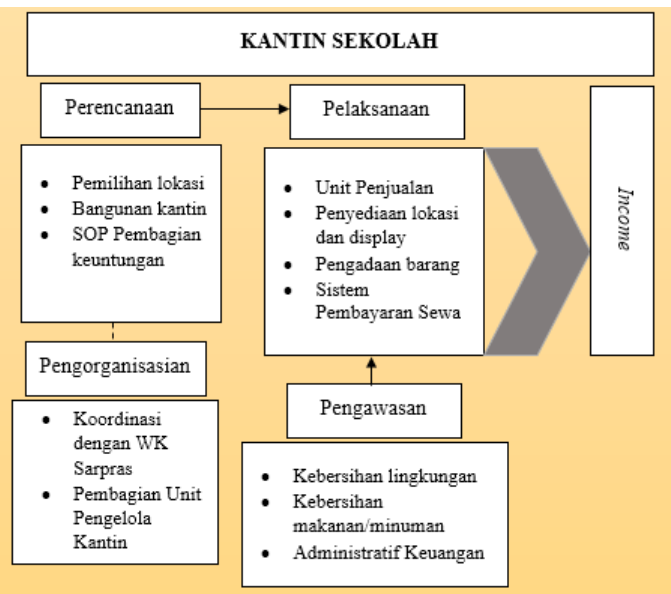

Gambar 8. Model Akhir Pola Pengelolaan Kantin Sekolah pada SMK

Diagram pada Gambar 8 dapat dijelaskan bahwa pengelolaan Kantin Sekolah dapat dilakukan dengan: (1) perencanaan meliputi: pemilihan lokasi, bangunan yang baik, dan SOP; (2) pengorganisasian meliputi koordinasi dengan WK Sarpras dan pembagian unit pengelola kantin; (3) pelaksanaan meliputi: unit penjualan, penyediaan lokasi dan display, pengadaan barang serta sistem pembayaran sewa; dan (3) pengawasan yang terdiri dari: pengawasan kebersihan lingkungan, kebersihan makanan/minuman, dan administratif keuangan.

\section{Pola Pengelolaan Kerja sama DU/DI pada SMK}

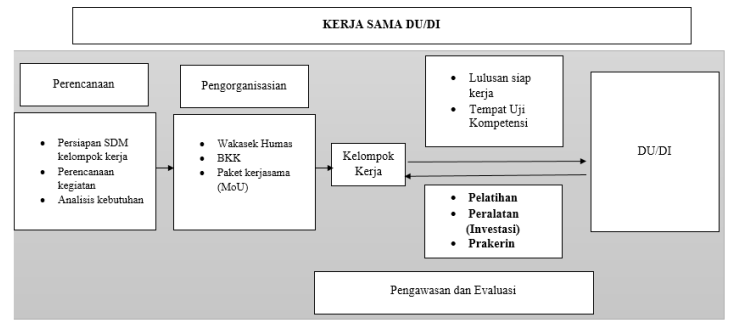

Gambar 9. Model Akhir Pola Pengelolaan Kerja sama DU/DI pada SMK

Menjalin kerjasama yang dilakukan antara SMK dan DU/DI bukan berupakan hal yang mudah karena model kerjasama/ kemitraan yang diinginkan adalah kerjasama yang saling menguntungkan. Hal yang 
perlu diperhatikan adalah pengelola SMK memerlukan kemampuan menjual (marketing capability) sehingga DU/DI tertarik dan yakin untuk memberikan sumber daya pendidikan. Marketing capability dapat dilakukan jika SMK memiliki sumber daya yang memiliki keunggulan sehingga dalam proses negosiasi SMK memiliki bargaining position yang baik. Perencanaan hingga pelaksanaan kerja sama dapat dilakukan dengan: (1) perencanaan SDM kelompok kerja dan kegiatan; (2) pengorganisasian tim kerja (BKK dan Wakasek Humas) dan persiapan MoU; dan (3) Model kerja sama yang dapat dilakukan, pihak DU/DI dapat memberikan: (1) program pelatihan dan instruktur; (2) peralatan pendukung; dan (3) tempat prakerin. Sedangkan pihak SMK dapat memberikan: (1) lulusan yang siap kerja; dan (2) tempat uji kompetensi.

\section{Pola Pengelolaan Unit Usaha Penyewaan pada SMK}

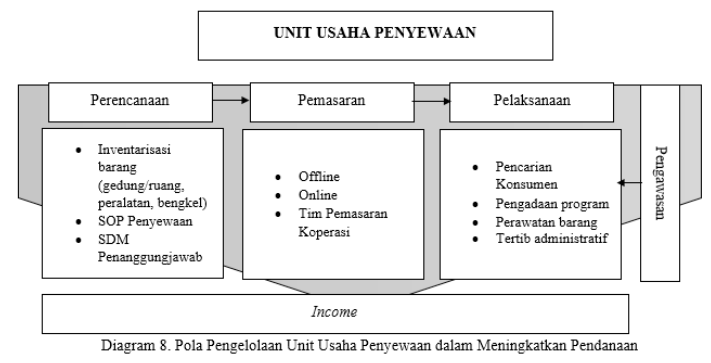

Gambar 10. Model Akhir Pola Pengelolaan Unit Usaha Penyewaan pada SMK

Gambar tersebut dapat dijelaskan bahwa pengelolaan Unit Usaha Penyewaan dapat dilakukan dengan: (1) perencanaan meliputi: inventarisasi barang, SOP, dan SDM; (2) pemasaran meliputi: offline, online, dan tim pemasaran koperasi; dan (3) pelaksanaan termasuk pencarian pelanggan, pelaksanaan program, perawatan barang, dan tertib administratif. Sebagai bentuk evaluasi dilakukan fungsi pengawasan.

\section{SIMPULAN DAN SARAN}

\section{Simpulan}

Berdasarkan hasil penelitian pengembangan model sumber dana pada SMK dapat disimpulkan sebagai berikut:
Pertama, sumber dana yang selama ini diterapkan di SMK negeri Bidang Keahlian Teknologi dan Rekayasa dapat diketahui bahwa: (1) sumber dana sebagian besar berasal dari pemerintah, baik pemerintah pusat, pemerintah daerah, maupun pemerintah kota dan berasal dari masyarakat; (2) sumber dana alternatif berasal dari penyewaan kantin, koperasi, dan kerja sama DU/DI; dan (3) Peran sumber dana alternatif terhadap anggaran belanja operasional sekolah secara umum sebesar $\leq 0,15 \%$. Adapun rincian masing-masing sekolah, yaitu: (a) sumber dana alternatif SMK Negeri 2 Yogyakarta berperan 0,07\% dari total belanja Rp 26.997.627.173; (b) sumber dana alternatif SMK Negeri 3 Yogyakarta berperan 0,15\% dari total belanja $\mathrm{Rp}$ 17.250.486.377.

Kedua, sumber dana yang selama ini diterapkan di SMK swasta Bidang Keahlian Teknologi dan Rekayasa dapat diketahui bahwa: (1) sumber dana sebagian besar berasal dari masyarakat dan bantuan pemerintah; (2) sumber dana alternatif berasal dari penyewaan kantin, unit produksi, koperasi; dan unit usaha lainnya; (3) Peran sumber dana alternatif terhadap anggaran belanja operasional sekolah secara umum sebesar $\leq 0,39 \%$. Adapun rincian masing-masing sekolah, yaitu: (a) sumber dana alternatif SMK Muhammadiyah 3 Yogyakarta berperan $0,36 \%$ dari total belanja Rp 11.258.728.500; (b) sumber dana alternatif SMK Perindustrian Yogyakarta berperan 0\% dari total belanja Rp 803.918.500; (c) sumber dana alternatif SMK PIRI 1 Yogyakarta berperan $0,28 \%$ dari total belanja $\mathrm{Rp}$ 1.568.006.000; dan (d) sumber dana alternatif SMK Taman Siswa Jetis Yogyakarta berperan 0,39\% dari total belanja $\mathrm{Rp} 1.003 .400 .000$.

Ketiga, grand design hasil pengembangan model sumber dana SMK negeri yaitu dengan menerapkan model pengelolaan sumber dana sekolah.

Keempat, grand design hasil pengembangan model sumber dana SMK swasta terdiri dari: (1) model pengelolaan sumber dana sekolah; dan (2) model pengembangan unit-unit usaha SMK.

Kelima, fungsi manajemen model pengelolaan sumber dana sekolah terdiri dari tahap: perencanaan, pengorganisasian, pelaksanaan, 
dan pengawasan. Pada tahap perencanaan, SMK melakukan evaluasi diri sekolah, yaitu mengevaluasi ketercapaian program pada tahun ajaran sebelumnya. Pada tahap pengorganisasian, dilakukan pembagian tugas antar pengelola sekolah dan pengelompokkan dana berdasarkan mata anggaran. Pada tahap ini peran kepala sekolah untuk melakukan koordinasi dan justifikasi agar tujuan efisiensi anggaran benar-benar terwujud. Pada tahap pembelanjaan, dilaksanakan sesuai prosedur yang telah disepakati dan dikendalikan serta dilakukan pengawasan baik internal maupun eksternal. Kemudian pada tahap pelaporan, pertanggungjawaban dibuat dalam bentuk laporan keuangan dan laporan kinerja. Sisa dana yang berasal penghematan anggaran dan keuntungan dari unit usaha sekolah dapat disimpan sebagai kas.

Keenam, fungsi manajemen model pengembangan unit-unit usaha sekolah di SMK dimulai dari tahap perencanaan, yaitu kepala sekolah dituntut untuk memiliki visi dan jiwa kewirausahaan sehingga dapat mengoptimalisasi sumber daya sekolah dan SDM di dalamnya. Pada tahap pengorganisasian dilakukan pembagian tugas antara WK Humas, WK Sarpras, bendahara, dan seorang manajer yang bertugas sebagai koordinator unit usaha sekolah. Pada tahap pelaksanaannya, unit usaha sekolah memegang prinsip partisipatif, transparan, dan akuntabilitas. Sifatnya komersial namun tetap mendukung proses belajar mengajar. Selain itu secara jelas mengatur tentang upah yang didapat bagi pengelola unit usaha tersebut. Unit usaha sekolah menjalankan manajemen produksi/ opersi masing-masing. Namun pada bagian pemasaran, koperasi sekolah dapat menjadi koordinator bagi UPS dan Unit Penyewaan. Selain itu, pengelolaan keuangan dilakukan secara terpusat dan terpadu.

Ketujuh, hasil uji internal yang dilakukan dapat disimpulkan bahwa ahli setuju: (1) komponen model telah lengkap $(84,5 \%)$; (2) struktur komponen model telah jelas $(86,3 \%)$; (3) hubungan antar komponen model telah jelas (80,4\%); (4) model memiliki keterbacaan yang baik $(82,2 \%)$; (5) model telah layak $(88,1 \%)$; dan (6) model efektif jika diimplementasikan $(93,3 \%)$.

\section{Saran}

Produk pengembangan disarankan untuk dimanfaatkan dalam hal:

Pertama, model pengembangan sumber dana alternatif pada SMK disarankan agar dapat diterapkan di SMK swasta yang lebih fleksibel dalam memanfaatkan potensi dan aset sekolah dibandingkan dengan SMK negeri.

Kedua, model pengelolaan sumber dana di SMK disarankan agar dapat dilakukan tahap evaluasi diri sekolah, hal ini bertujuan agar RAPBS disusun berdasarkan evaluasi terhadap kinerja yang telah dilakukan selama satu tahun ajaran sebelumnya.

Ketiga, pemanfaatan UPS dan koperasi sekolah pada model ini selain bertujuan menghasilkan income, disarankan agar dapat dimanfaatkan dalam proses pembelajaran bagi peserta didik khususnya pada mata pelajaran Prakarya dan Kewirausahaan.

Keempat, kantin sekolah memiliki potensi yang cukup baik sehingga disarankan agar dapat lebih maksimal dalam operasional, pengelolaan, dan pengembangannya dengan cara harga sewa yang ideal, uang sewa dibayar per tahun, dan pembagian keuntungan yang jelas.

Kelima, model pengembangan unit-unit usaha, yang terdiri dari unit-unit usaha sekolah: UPS, koperasi, kantin, kerja sama DU/DI, dan unit penyewaan pada SMK disarankan agar dapat diterapkan sehingga nantinya menjadi ciri sekolah kejuruan yang mandiri terhadap pendanaan dan mengurangi beban operasional sekolah.

Keenam, model pengembangan sumber dana alternatif pada SMK disarankan agar dapat didukung oleh regulasi yang jelas, baik dari tingkat eksternal (Peraturan Menteri Pendidikan) sampai tingkat internal (SK Kepala Sekolah) sehingga akan mempermudah dan mendukung pelaksanaan pengembangan sumber dana alternatif yang dapat dilakukan SMK.

\section{DAFTAR PUSTAKA}

Direktorat Pembinaan SMK. (2014). Petunjuk Teknis BOS SMK. Jakarta: Direktorat PSMK. 
Direktorat Pendidikan Menengah. (2006). Kurikulum SMK 2006. Jakarta: Dikmenjur.

Fattah, Nanang. (2012). Standar pembiayaan pendidikan. Bandung: Rosda.

Gasskov, V. (2000). Managing vocational training system. A handbook for senior administrators. Geneva: International Labour Organization.

Gill, I. S., Fluitman, F., \& Dar, A. (2008). Vocational education and training reform. New York: Oxford University Press, Inc

Greenwald, R., Hedges, L.V, \& Laine, R.D. (1996). The effect of school resources on student achievement. Review of Educational Research. Volume 66, No 3. $361-396$.

Greenwood, M. (2005). A-levels are not the only route vocational education can lead to university as well. Journal Education and Training. Volume 47. 00440-0912.

Harris, R., Simons, M., \& Moore, J. (2005). A huge learning curve TAFE practitioners ways of working with private enterprises. South Australia:NCVER.

Klein, S. (2001). Financing vocational education: a state policymaker's guide. Sorting out the byzantine world of state funding formulas, district cost variation, and option for supporting the provision of equitable, quality vocational education in high school. (Instructional Resource No.30). Athens, GA and College Park, MD: Educational Resources Information Center (ERIC Document Reproduction Service No.ED457329).

Lulusan SMK dominasi pengangguran. (2013, 6 November). Republika. Diakses tanggal 1 Agustus 2014, dari http:// www.republika.co.id/berita/nasional/ umum/14/05/02/n4y7k0-indonesiaharus-manfaatkan-bonus-demografi
Mendiknas. (2009). Peraturan Menteri Pendidikan Nasional Nomor 69, Tahun 2009, tentang Standar Biaya Nonpersonalia Tahun 2009 untuk SD/ MI, SMP/MTs, SMA/MA, SMK, SDLB, SMPLB, SMALB.

Milles, M.B \& A.M. Huberman. (1994). Qualitative data analysis. California: SAGE Publications Inc.

Nurhadi, Muljani A (2011). Dilema kebijakan pendanaan pendidikan. Jakarta: Nurhadi Center.

Pavlova, M. (2009). Technology and vocational education for sustainable development, empowering individuals for the future. Queensland: Springer.

Pemerintah siapkan 300 smk rujukan yang berkinerja unggul. (2014, 16 April). Setkab. Diambil pada tanggal 2 Agustus 2014, dari http://old.setkab.go.id/berita12756-pemerintah-siapkan-300-smkrujukan-yang-berkinerja-unggul.html

Specht, G., Feder, F., \& Aipperspach, C. (2014). Cooperation with the business community improving demandorientation of tvet. Makalah disajikan dalam Regional TVET Conference 2014. 1 - 2 April 2014. Shangri La Hotel. Jakarta.

The global competitiveness report 2013 2014. (2014). Geneva: World Economic Forum.

Windarto, Rony. (2013). Minat Siswa SMP Negeri ke SMK Ditinjau dari Sosial Ekonomi Keluarga di Kabupaten Bantul. Jurnal Pendidikan Vokasi. Vol.3 No.1 Februari. 